Diana Febriyanti Quraini, Farida Wahyu Ningtyias, dan Ninna Rohmawati Jurnal Promkes: The Indonesian Journal of Health Promotion and Health Education Vol. 8 No. 2 (2020) 154-162 doi: 10.20473/jpk.V8.12.2020.154-162

\title{
Perilaku Kepatuhan Konsumsi Tablet Tambah Darah Remaja Putri di Jember, Indonesia
}

\section{Compliance Behavior of Iron Tablet Suplement Consumption to Adolescent Girls In Jember, Indonesia}

\author{
Diana Febriyanti Quraini ${ }^{1)}$, Farida Wahyu Ningtyias ${ }^{1)}$, Ninna Rohmawati ${ }^{1)}$ \\ 1 Departemen Gizi Kesehatan Masyarakat, Fakultas Kesehatan Masyarakat, Universitas Jember, \\ Kember, Indonesia \\ Email: farida.fkm@unej.ac.id
}

\begin{abstract}
Background: Anaemia in teenage girls is an important nutritional problem to be prevented and to overcome since it affects the first 1,000 days of life period. One of the anaemia precaution strategies in adolecents girls and women of childbearing age (WCA) is by consuming one iron tablet supplement (ITS) every week. An indicator of the success of the program is the adherence of teenage girls and WCA in the consumption of ITS. An individual's behavior can be predicted from the individual's intentions formulated in the theory of planned behavior (TPB). Objective: This study aimed to analyze the relation of perceived behavioral control factors related to the intention of the adherence of teenage girls' regular consumption of ITS. Methods: The method in this research was analytic observational with a cross-sectional approach. A sample of 328 adolescent girls was taken by the stratified proportional random sampling method. The research variable was the perception of behavioral control, and intention to comply with ITS was analyzed by ChiSquare statistical test. Result: In this study, the results showed that most people who are $\leq 13$ years old or the seventh-grade students experienced normal puberty and got the symptoms of low anaemia, the majority of them had normal nutritional status. There was a relationship between perceived behavioral control and intentions to compliance behaviour to regular ITS consumption. The majority of respondnts had strong behaviour control $(52,7 \%)$ and intenttion to obey $(57 \%)$ ( $P$ Value $=0.000 ; O R=3.906 ; 95 \% \mathrm{Cl}=1.906$ 6.640). Conclusion: Teenage girls with strong perceived behavioral control will have a positive intention of the adherence of teenage girls' regular consumption of ITS 3.906 times compared with teenage girls with weak perceived behavioral control.
\end{abstract}

Keywords: Anaemia, Perceived behavioral control, Iron Tablet Supplement

\begin{abstract}
ABSTRAK
Latar Belakang: Anemia merupakan masalah gizi pada remaja putri yang perlu dicegah dan ditanggulangi karena akan berdampak pada periode 1000 hari pertama kehidupan (HPK). Pemerintah memprioritaskan program suplementasi tablet tambah darah (TTD) remaja putri dan wanita usia subur (WUS) untuk menurunkan prevalensi anemia pada kelompok tersebut. Salah satu indikator keberhasilan program tersebut yakni kepatuhan remaja putri dalam mengonsumsi TTD. Perilaku seorang individu dapat diprediksi dari niat individu tersebut yang dirumuskan dalam theory of planned behavior (TPB). Tujuan: Menganalisis hubungan kontrol perilaku dengan niat patuh dalam mengonsumsi TTD secara teratur.Metode: Jenis penelitian ini adalah analitik observasional dengan pendekatan cross sectional. Sampel berjumlah 328 remaja putri yang diambil dengan metode stratified proporsional random sampling. Variabel penelitian adalah persepsi kontrol perilaku dan niat patuh minum TTD yang dianalisis dengan uji statistik ChiSquare. Hasil: Hasil penelitian ini didapatkan 51,2\% responden berumur $\leq 13$ tahun, 85,7\% responden mengalami pubertas yang normal. Mayoritas responden memiliki kontrol perilaku $(52,7 \%)$ dan niat (57\%)Terdapat hubungan antara kontrol perilaku $(P$ Value $=0,000$; $O R=3,906 ; 95 \% C l=1,906-6,640)$ dengan niat patuh konsumsi TTD teratur. Kesimpulan: Remaja yang memiliki kontrol perilaku yang kuat akan memiliki niat patuh konsumsi TTD
\end{abstract}


teratur 3,906 kali dibandingkan remaja putri dengan kontrol perilaku lemah terhadap konsumsi TTD.

Kata Kunci: Anemia, Persepsi Kontrol Perilaku, Niat Patuh, Tablet Tambah Darah (TTD)

\section{PENDAHULUAN}

Prevalensi anemia pada ibu hamil berdasarkan data Riset Kesehatan Dasar (RISKESDAS) 2013 sebesar 37,1\%, hal ini adalah dampak lanjut dari tingginya prevalensi anemia remaja putri $(25 \%)$ dan wanita usia subur $(17 \%)$ (Kementerian Kesehatan RI, 2016). Jenis penyakit anemia yang berisiko diderita remaja putri pada masa pubertas adalah anemia gizi besi (Adriani and Wirjatmadi, 2012).

Remaja putri yang mengalami anemia memiliki risiko menjadi ibu hamil anemia. Berbagai upaya perlu dilakukan untuk mencegah dan menangani anemia pada remaja putri. Kondisi ibu hamil yang mengalami anemia dapat mempengaruhi periode 1000 hari pertama kehidupan (HPK). Dampak yang ditimbulkan antara lain adanya risiko melahirkan bayi berat lahir rendah (BBLR) yang berisiko 3,63 kali menjadi bayi usia dibawah dua tahun (baduta) stunting (Kementerian Kesehatan RI, 2016).

Gerakan Upaya Percepatan Perbaikan Gizi untuk memutus mata rantai stunting diprioritaskan pada 1000 HPK melalui intervensi spesifik dan sensitif yang antara lain terintegrasi dengan program penanggulangan anemia kepada sasaran remaja putri dan wanita usia subur (WUS) (Kementerian Kesehatan RI, 2016). Salah satu upaya intervensi yang dilakukan yakni suplementasi zat besi atau tablet tambah darah (TTD). Pemberian asupan zat besi yang cukup memiliki fungsi yakni untuk meningkatkan pembentukan hemoglobin (Kementerian Kesehatan RI, 2016).

Pemerintah Indonesia melakukan intensifikasi program pencegahan dan penanggulangan anemia pada remaja putri dan WUS dengan memprioritaskan pemberian TTD satu tablet setiap minggu untuk mengurangi $50 \%$ prevalensi anemia pada remaja putri dan WUS di tahun 2025. Program suplementasi TTD remaja putri usia 12-18 tahun dilakukan di sekolah melalui unit Usaha Kesehatan Sekolah (UKS). Hasil wawancara dengan pemegang program TTD Remaja putri
Dinas Kesehatan Kabupaten Jember, Kabupaten Jember telah menjalankan program tersebut sejak bulan Februari 2018 melalui UKS di setiap SMP dan SMA sederajat.

Kepatuhan remaja putri dan WUS mengkonsumsi TTD merupakan salah satu indikator keberhasilan program pencegahan dan penanggulangan anemia pada remaja putri dan WUS (Kementerian Kesehatan RI, 2016). Ketidakpatuhan dalam meminum tablet tambah darah menghambat manfaat suplementasi zat besi (Fe) tersebut (Yuniarti; Rusmilawaty; Tunggal, 2015). Ketidakpatuhan remaja putri konsumsi TTD dapat disebabkan perasaan bosan atau malas, rasa dan aroma yang tidak enak dari TTD (Aditianti, Permanasari and Julianti, 2015), efek samping yang dirasakan setelah mengkonsumsi TTD, seperti mual dan muntah, nyeri atau perih di ulu hati dan tinja berwarna hitam (Kementerian Kesehatan RI, 2016; Yuniarti; Rusmilawaty; Tunggal, 2015).

Kepatuhan dalam mengonsumsi TTD merupakan suatu bentuk perilaku sehingga kecenderungan remaja putri untuk patuh dalam konsumsi TTD secara teratur dapat dianalisis menggunakan teori perilaku. Teori perilaku yang dapat digunakan salah satunya adalah Theory of Planned Behavior (TPB). Perilaku seorang individu dapat diperkirakan dari niat individu tersebut yang dirumuskan dalam TPB (Ajzen, 2005).

Perilaku patuh merupakan hasil dari niat remaja putri tersebut untuk mengkonsumsi TTD dengan frekuensi satu tablet setiap minggu sepanjang tahun. TPB atau teori perilaku terencana menyebutkan dimensi yang mempengaruhi terbentuknya niat individu adalah sikap, norma subjektif, dan persepsi kontrol perilaku (kontrol perilaku) (Ramdhani, 2016).

Persepsi kontrol perilaku atau kontrol perilaku adalah persepsi individu mengenai sulit atau mudahnya mewujudkan suatu perilaku tertentu (Ajzen, 2005). Semakin besar faktor pendukung dan kesempatan yang ada 
serta semakin sedikit hambatan yang dimiliki, maka akan semakin besar pula persepsi individu untuk dapat mengontrol atau melakukan perilaku tersebut sehingga menyebabkan lebih kuat untuk mewujudkan niat (Wikamorys and Rochmach, 2017).

$$
\text { Wilayah kerja Puskesmas }
$$

Sumbersari, Kecamatan Sumbersari, Kabupaten Jember memiliki jumlah remaja usia sekolah dengan status anemia tertinggi dibandingkan puskesmas lain. Jumlah remaja putri usia 10-14 tahun yang mengalami anemia sebesar 237 remaja dan usia 15-19 tahun sebanyak 330 remaja berstatus anemia. Penelitian ini dilakukan untuk menganalisis hubungan kontrol perilaku dengan niat patuh konsumsi TTD teratur pada remaja putri di wilayah kerja Puskesmas Sumbersari Kabupaten Jember.

\section{METODE}

Penelitian ini termasuk dalam penelitian analitik dengan desain cross sectional. Penelitian analitik memiliki tujuan utama untuk mencari hubungan antara variabel penelitian Desain penelitian cross sectional mempelajari hubungan antara faktor risiko dengan penyakit (efek), pengukuran terhadap variabel bebas, dan terikat dilakukan sekali dalam satu waktu bersamaan (Sastroasmoro and Ismael, 2011).

Penelitian ini menggunakan teknik pengambilan sampel dengan metode multi stage random sampling. Langkah pengambilan sampel dalam penelitian ini terdiri atas dua tahap. Tahap pertama dengan menentukan sampel sekolah SMP/Sederajat menggunakan cluster sampling. Tahap kedua yakni menentukan responden penelitian dari setiap sekolah yang terpilih menggunakan teknik stratified proporsional random sampling. Lokasi penelitian bertempat di lima sekolah yang mewakili wilayah kerja Puskesmas Sumbersari, yaitu SMPN 3 Jember, SMPS IT Al Ghozali, SMPS Darul Istiqomah, SMPS Agus Salim, dan SMPN 9 Jember. Pengambilan data dilakukan selama Agustus hingga Oktober 2018. Penelitian ini memiliki sertifikat etik dengan nomor sertifikat No.278/UN25.8/KEPK/DL/2019. Responden yang terlibat dalam penelitian ini yakni 328 orang remaja putri. Responden yang terpilih telah memenuhi kriteria inklusi. Kriteria tersebut antara lain merupakan siswi SMP atau sederajat, tempat tinggal di Jember. Syarat yang kedua adalah sedang tidak sakit dan masuk sekolah saat pengambilan data, serta yang ketiga bersedia menjadi responden penelitian.

Variabel bebas dalam penelitian ini adalah persepsi kontrol perilaku remaja putri. Variabel terikat dalam penelitian ini adalah niat patuh remaja putri untuk konsumsi TTD teratur. Sebagai data tambahan juga dilakukan pengambilan data tentang karakteristik responden, usia menarche pertama, gejala anemia, dan status gizi.

Teknik pengumpulan data pada penelitian ini menggunakan angket penelitian dengan penilaian scoring. Variabel persepsi kontrol perilaku dengan rentang nilai 0-6, dikategorikan menjadi kontrol perilaku lemah (0-3) dan kuat (4-6). Variabel niat memiliki rentang nilai 0-8 yang dikategorikan menjadi niat tidak patuh konsumsi TTD (0-4) dan niat patuh konsumsi TTD (5-8) (Rismalinda, 2017).

Pengumpulan data juga dilakukan melalui pengukuran tinggi badan (TB) dan berat badan (BB) untuk menghitung status gizi menurut Indeks Massa Tubuh (IMT)/umur. Pengukuran tinggi badan menggunakan mikrotoa dengan posisi frankfurtplane dan pengukuran berat badan memakai timbangan injak dengan ketelitian 0,1 $\mathrm{mm}$.

Data kontrol perilaku dan niat selanjutnya dianalisis secara deskriptif dan analitik menggunakan uji chi-square untuk mengetahui hubungan antarvariabel independen dengan variabel dependen. Uji statistik tersebut menggunakan $(\alpha=5 \%)$. Data karakteristik responden yang diperoleh, kemudian diolah dan disajikan dalam bentuk tabel dan dianalisis secara deskriptif.

\section{HASIL DAN PEMBAHASAN}

Distribusi frekuensi karakteristik responden disajikan Tabel 1. Tabel 1 menunjukkan bahwa diketahui mayoritas responden berumur $\leq 13$ tahun $(51,2 \%)$, mengalami pubertas normal $(85,7 \%)$, mengalami gejala anemia pada level rendah $(85,4 \%)$, dan mayoritas memiliki status gizi normal $(81,4 \%)$. 
Tabel 1. Karakteristik Unurponden Menarche pertama, Gejala Anemia, dan Status Gizi

\begin{tabular}{lrr}
\hline \multicolumn{1}{c}{ Karakteristik } & $\mathbf{n}$ & $\%$ \\
\hline Umur & & \\
\hline$\leq 13$ & 168 & 51,2 \\
14 & 110 & 33,5 \\
$\geq 15$ & 50 & 15,3 \\
\hline Usia menarche pertama & & \\
\hline Belum menstruasi & 38 & 11,6 \\
Pubertas dini & 9 & 2,7 \\
Pubertas normal & 281 & 85,7 \\
\hline Gejala anemia & & \\
\hline Rendah & 280 & 85,4 \\
Tinggi & 48 & 14,6 \\
\hline Status gizi (IMT) & & \\
\hline Kurus & 3 & 0,9 \\
Normal & 267 & 81,4 \\
Gemuk & 43 & 13,1 \\
Obesitas & 16 & 4,6 \\
\hline Total & 328 & 100 \\
\hline
\end{tabular}

Umur

Umur responden dalam penelitian ini yaitu umur 11-16 tahun. Umur ini termasuk dalam kategori remaja awal (11-14 tahun) dan remaja menengah (15-17 tahun (Irianto, 2014). Ciri khas remaja pada usia ini (12-16 tahun) antara lain cenderung lebih mempercayai apa yang ada di dalam pikirannya, tidak mau menerima sebuah pendapat tanpa alasan yang masuk akal. Ciri khas lainnya yakni remaja memerlukan orang yang dapat mengarahkan mereka pada pematangan diri yang utuh (Adriani and Wirjatmadi, 2012).

Hasil penelitian ini didapatkan paling banyak responden adalah remaja awal $(51,2 \%)$ berumur $\leq 13$ tahun. Penelitian sebelumnya mengungkapkan bahwa karakteristik remaja awal ditandai oleh terjadinya perubahan-perubahan psikologi. Perubahan tersebut antara lain krisis identitas, jiwa yang labil, pentingnya teman dekat, terdapat pengaruh teman sebaya (peer group) yang dominan seperti bertingkah laku sama, remaja ini hanya tertarik pada keadaan sekarang bukan masa depan (Fishbein and Ajzen, 2011). Remaja dapat memahami bahwa tindakan saat ini dapat memiliki efek pada masa yang akan datang, dengan demikian seorang remaja mampu memperkirakan konsekuensi dari tindakannya, termasuk terdapat kemungkinan yang dapat membahayakan dirinya (Dewi, Oktiawati and Saputri, 2015). Remaja putri pada penelitian ini telah mampu berencana untuk patuh atau tidak mengonsumsi TTD teratur seminggu sekali sepanjang tahun dengan benar dan telah mampu mempertimbangkan konsekuensi atas perilaku tersebut.

\section{Usia Menarche Pertama}

Usia menarche mayoritas responden $(85,7 \%)$ terjadi pada umur 12 13 tahun sehingga dapat disimpulkan remaja putri pada penelitian ini memiliki status pubertas normal. Kebutuhan zat besi remaja putri pada penelitian ini meningkat karena mayoritas responden $(88,4 \%)$ telah memasuki usia pubertas dan mengalami menstruasi setiap bulannya (Adriani and Wirjatmadi, 2012). Remaja putri akan berisiko menderita anemia ketika kebutuhan zat besi tidak terpenuhi. Penelitian yang dilakukan di Pekanbaru menunjukkan bahwa terdapat hubungan yang signifikan antara menstruasi dengan kejadian anemia pada remaja putri (Irianti, 2019).

Menstruasi dini disebabkan oleh beberapa faktor. Faktor-faktor tersebut antara lain faktor hormonal yang tidak seimbang dan asupan makanan yang berlebihan namun tidak diselingi dengan aktifitas fisik yang menyebabkan berat badan tubuh berlebih (Ekawati and Buton, 2018). Hubungan usia menarche ibu dengan putrinya adalah sangat erat, faktor lain yang berperan penting adalah status gizi, remaja putri gemuk akan mendapat menarche lebih awal daripada yang kurus (Irianto, 2014).

\section{Gejala Anemia}

Hasil penelitian ini mendapatkan sebagian besar responden (85,4\%) mengalami gejala anemia yang rendah. Responden dengan gejala anemia rendah bukan berarti tidak mengalami anemia karena remaja akan merasakan gejala anemia ketika penyakit anemia yang diderita telah parah. Penderita anemia ringan belum memiliki gejala maupun tanda dari penyakit anemia (WHO, 2011).

Anak usia 12-14 tahun menderita anemia ringan jika level hemoglobin 11$11,9 \mathrm{~g} / \mathrm{dl}$, anemia sedang $8-10,9 \mathrm{~g} / \mathrm{dl}$, dan anemia berat $<8 \mathrm{~g} / \mathrm{dl}$. Anemic syndrome atau gejala anemia umum dapat dijumpai pada anemia dengan kadar hemoglobin kurang dari 7-8 g/dl (WHO, 2011). Gejala yang ditimbulkan

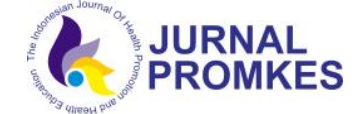

(C)2020. Jurnal Promkes: The Indonesian Journal of Health Promotion and Health Education. Open Access under CC BY-NC-SA License.

Received: 05-11-2019, Accepted: 14-09-2020, Published Online:28-09-2020 
antara lain badan terasa lemah, telinga mendenging, mata berkunang-kunang, cepat lelah, serta lesu.

\section{Status Gizi menurut IMT/U}

Hasil penelitian menunjukkan mayoritas memiliki status gizi normal $(81,4 \%)$. Hasil ini sejalan dengan penelitian di SMAN 2 Jember bahwa status gizi remaja putri mayoritas adalah normal $(78,1 \%)$ (Nurcahyani, 2014). Hasil penelitian ini juga didukung oleh data RISKESDAS 2013, prevalensi status gizi (IMT/U) remaja putri umur 13-15 tahun di Indonesia sebesar 80,8\% berstatus gizi normal (Kementerian Kesehatan RI, 2013).

Berat badan normal adalah idaman setiap individu agar tercapai tingkat kesehatan optimal. Keuntungan yang didapatkan dengan berat badan normal diantaranya penampilan baik, lincah, dan memiliki risiko rendah terutama penyakit infeksi maupun degeneratif. Responden penelitian mayoritas memiliki status gizi normal, namun bukan berarti tidak memiliki risiko anemia. Hasil penelitian di Peterongan, Jombang menunjukkan tidak ada hubungan yang bermakna antara status gizi, energy, protein, dan vitamin C dengan kejadian anemia pada remaja putri. Artinya, meskipun mayoritas responden memiliki status gizi yang normal tidak menutup kemungkinan remaja putri tersebut untuk mengalami anemia (Sya'Bani and Sumarmi, 2016).

Pernyataan ini didukung oleh hasil penelitian mendapatkan bahwa tingkat konsumsi protein, lemak, dan karbohidrat berhubungan dengan status gizi remaja putri. Karbohidrat, lemak, dan protein merupakan zat gizi penyuplai energi terbesar bagi tubuh (Nurcahyani, 2014). Zat besi adalah zat gizi mikro dan asupan zat gizi mikro tidak mempengaruhi status gizi berdasarkan IMT/U karena memiliki kandungan energi yang sedikit, dan jika terjadi kekurangan mungkin sudah berlangsung lama (Rosmalina and Ernawati, 2010).

\section{Kontrol Perilaku}

Hasil penelitian pada Tabel 2 menunjukkan 173 respoden $(52,7 \%)$ memiliki kontrol perilaku yang kuat untuk konsumsi TTD teratur. Hasil ini sejalan dengan penelitian yang menyebutkan sebanyak $62 \%$ remaja putri memiliki kontrol perilaku yang baik (Cahyaningrum, 2014). Kontrol perilaku mengindikasikan bahwa motivasi seseorang dipengaruhi oleh bagaimana individu tersebut memandang tentang ada atau tidaknya faktor yang memudahkan atau mempersulit jika suatu perilaku dilakukan (Ajzen, 2005).

Tabel 2. Karakteristik

Responden berdasarkan Kontrol Perilaku dan Niat Konsumsi TTD Teratur

\begin{tabular}{lcc}
\hline \multicolumn{1}{c}{ Variabel } & n & $\%$ \\
\hline Kontrol Perilaku & & \\
\hline Lemah & 155 & 47,3 \\
Kuat & 173 & 52,7 \\
\hline Niat & & \\
\hline Niat Tidak Patuh & 141 & 43 \\
Niat Patuh & 187 & 57 \\
\hline Total & 328 & 100 \\
\hline
\end{tabular}

Kontrol perilaku adalah persepsi individu mengenai mudah atau sulitnya mewujudkan suatu perilaku yang ditentukan dua faktor. Faktor yang pertama yakni keyakinan individu terhadap ketersediaan sumber daya berupa peralatan, kompatibilitas, kompetensi. Faktor kedua yakni kesempatan (control belief strength) yang mendukung atau menghambat perilaku yang akan diprediksi dan besarnya peran sumber daya (power of control factor) dalam mewujudkan perilaku tersebut (Ramdhani, 2016).

Kontrol perilaku kuat terhadap konsumsi TTD teratur seminggu sekali akan timbul jika responden setuju dengan pernyataan yang mendukung (favorable) terhadap perilaku patuh konsumsi tablet tambah darah teratur, yaitu pertanyaan tentang TTD selalu tersedia dari puskemas, efek samping yang dirasakan setelah mengonsumsi tablet tambah darah adalah hal yang tidak membahayakan bagi kesehatan, memiliki kewajiban untuk konsumsi TTD seminggu sekali sepanjang tahun. Hasil angket menunjukkan responden yang memiliki kontrol perilaku kuat, sebagian besar setuju dengan tablet tambah darah selalu tersedia dari puskemas dan tidak setuju pada pernyataan efek samping yang dirasakan setelah mengonsumsi tablet tambah darah adalah hal yang tidak membahayakan bagi kesehatan. Hasil ini selaras dengan hasil penelitian (Putra, Sukaatmadja and Yasa, 2016).

$$
\text { Kontrol perilaku lemah }
$$

responden akan muncul jika setuju 
dengan pernyataan yang negatif (unfavorable) terhadap konsumsi tablet tambah darah teratur, yaitu:

"Efek samping yang dirasakan setelah mengonsumsi TTD membuat saya ingin berhenti mengonsumsi tablet tambah darah secara teratur, saya akan kesulitan untuk mendapatkan tablet tambah darah pada masa liburan semester sekolah, dan saya tidak bersalah jika saya mengonsumsi tablet tambah darah dua minggu sekali ketika masa libur sekolah".

Responden dengan kontrol perilaku yang lemah sebagian besar setuju pada pernyataan efek samping yang dirasakan membuat ingin berhenti dan merasa tidak bersalah jika responden mengonsumsi tablet tambah darah dua minggu sekali ketika masa libur sekolah.

Perceived behavior control (PBC) merupakan persepsi individu terhadap mudah atau tidaknya individu tersebut dalam melakukan perilaku dan diasumsikan merupakan refleksi dari pengalaman yang telah terjadi sebelumnya juga berbagai hambatan yang diantisipasi. Semakin banyak faktor pendukung dan sedikit faktor penghambat yang dirasakan oleh individu dalam berperilaku, maka semakin besar kontrol yang mereka rasakan atas perilaku tersebut, begitu pula sebaliknya. Persepsi tersebut ditentukan oleh keyakinan seseorang, untuk mengendalikan faktor yang menghambat ataupun yang mendorong munculnya perilaku (Ajzen, 2005). Keyakinan ini dapat diakibatkan oleh pengalaman masa lalu dengan tingkah laku tersebut, tetapi juga dapat dipengaruhi oleh informasi yang tidak langsung akan tingkah laku tersebut yang diperoleh dengan mengamati pengalaman orang yang dikenal atau teman, sedangkan faktor yang dikontrol adalah faktor internal dan eksternal (Lestarina, 2018).

\section{Niat Patuh Konsumsi TTD}

Niat merupakan pendahulu dari suatu perilaku yang sudah direncanakan sebelumnya (Ajzen, 2005). Hasil penelitian pada Tabel 2 menunjukkan sebanyak 187 respoden (57\%) dari total 328 respoden memiliki niat patuh konsumsi TTD teratur. Hasil ini sejalan dengan penelitian sebanyak 57,7\% remaja putri memiliki niat yang baik dalam mengonsumsi TTD (Cahyaningrum, 2014).

Niat patuh mengonsumsi TTD pada remaja putri akan muncul jika responden setuju dengan pernyataan yang mendukung (favorable) terhadap perilaku patuh konsumsi tablet tambah darah teratur, yaitu:

1. Rencana untuk saling mengingatkan dengan teman dekat dalam konsumsi TTD teratur

2. Rencana untuk mengatur alarm hp milik remaja atau keluarga atau membuat tulisan pengingat di kalender untuk jadwal minum tablet tambah darah agar dapat teratur meminumnya saat libur sekolah

3. Meminta keluarga mengingatkan untuk minum TTD pada saat libur sekolah

4. Mengonsumsi sumber protein hewani seperti hati, ikan, telur atau sumber vitamin C seperti jeruk dan pepaya setelah minum tablet tambah darah agar penyerapan zat besi dalam tubuh menjadi maksimal.

Sebaliknya, niat tidak patuh responden akan muncul jika setuju dengan pernyataan yang negatif (unfavorable) terhadap konsumsi tablet tambah darah teratur, yaitu antara lain:

1. Berencana untuk menghindari jadwal minum TTD di sekolah karena tidak ingin meminumnya

2. Berencana tidak mengonsumsi TTD secara teratur seminggu sekali ketika hari libur semester ganjil atau kenaikan kelas

3. Jika memiliki aktivitas yang padat di hari jadwal minum TTD, tidak akan meluangkan waktu untuk meminumnya

4. Akan minum tablet tambah darah dengan minum teh atau kopi atau susu.

Hasil angket pada pernyataan niat, responden yang memiliki niat patuh untuk konsumsi TTD mayoritas setuju pada pernyataan (rencana untuk saling mengingatkan dengan teman dekat dalam konsumsi TTD teratur dan akan meminta keluarga mengingatkan untuk minum tablet tambah darah pada saat libur sekolah). Responden dengan niat tidak patuh konsumsi TTD sebagian besar setuju dengan pernyataan (berencana tidak mengonsumsi tablet tambah darah 
secara teratur seminggu sekali ketika hari libur semester ganjil atau kenaikan kelas dan berencana untuk menghindari jadwal minum TTD di sekolah karena tidak ingin meminumnya).

Kontrol Perilaku dengan Niat Patuh Konsumsi TTD pada Remaja Putri

Hubungan kontrol perilaku dengan niat patuh konsumsi TTD teratur diperoleh melalui analisis bivariabel dengan menggunakan uji chi-square. Hasil uji statistik didapatkan tidak ada cell dengan nilai expected $<1$ dan tidak terdapat cell dengan nilai expected $<5$ lebih dari 20\%, sehingga memenuhi persyaratan menggunakan uji chi- square. Hasil uji chi-square antara variabel norma subjektif dengan niat didapatkan $P$ Value 0,000 , artinya Ho ditolak. Hasil tersebut menunjukkan terdapat hubungan yang signifikan antara variabel kontrol perilaku dengan niat patuh konsumsi TTD secara teratur karena nilai $P$ Value $(0,000)<a(0,05)$. Nilai OR yang diperoleh sebesar 3,906, hasil analisis tersebut menunjukkan bahwa remaja yang memiliki kontrol perilaku yang kuat akan 3,906 kali memiliki niat patuh konsumsi TTD teratur dibandingkan dengan remaja yang mempunyai kontrol perilaku yang lemah.

Tabel 3. Tabulasi Silang antara Kontrol Perilaku dan Niat Konsumsi TTD Teratur

\begin{tabular}{lrrrrrr}
\hline \multirow{2}{*}{ Kontrol } & \multicolumn{3}{c}{ Niat } & \multicolumn{2}{c}{ Total } \\
\cline { 2 - 6 } Perilaku & \multicolumn{2}{c}{ Tidak patuh } & \multicolumn{2}{c}{ Patuh } & \multicolumn{2}{c}{} \\
\cline { 2 - 7 } & \multicolumn{1}{c}{ Frekuensi } & Persentase & Frekuensi & Persentase & Frekuensi & Persentase \\
\hline Lemah & 93 & 28,4 & 62 & 18,9 & 155 & 47,3 \\
Kuat & 48 & 14,6 & 125 & 38,1 & 173 & 52,7 \\
\hline Total & 141 & 43 & 187 & 57 & 328 & 100 \\
\hline
\end{tabular}

Hasil uji chi-square antara variabel kontrol perilaku dengan niat menunjukkan terdapat hubungan bermakna secara statistika, artinya responden yang memiliki keinginan untuk patuh konsumsi TTD teratur memiliki kontrol perilaku yang kuat. Penelitian ini sejalan dengan hasil penelitian di Jakarta mendapatkan terdapat pengaruh variabel kontrol perilaku terhadap niat merokok pada remaja di Jakarta (Rosdiana, 2011). Penelitian lain mendapatkan bahwa kontrol perilaku berhubungan positif dengan niat merokok pada siswa SMP di kota Bandung. Artinya, semakin tinggi kontrol perilaku yang dirasa remaja terhadap perilaku merokok, maka semakin tinggi pula niat untuk merokok. Persepsi remaja mengenai mudah atau sulitnya mewujudkan suatu perilaku berasal dari keyakinan mengenai ketersediaan sumberdaya dalam hal ini batang rokok yang mudah didapatkan dan dengan harga yang masih dapat dijangkau (Sagitania, 2017).

Kontrol perilaku mirip seperti self efficacy atau efikasi diri (Ajzen, 2005). Efikasi diri adalah keyakinan individu bahwa ia akan berhasil menguasai keterampilan yang dibutuhkan untuk menyelesaikan tugas-tugas tertentu. Penelitian yang dilakukan pada remaja di Surabaya mendapatkan bahwa efikasi diri yang dirasa remaja putri berhubungan dengan niat untuk konsumsi TTD (Aprianti, Sari and Kusumaningrum, 2018). Sama dengan persepsi positif remaja putri akan ketersediaan TTD dan kemudahan untuk mendapatkannya terutama saat libur semester akan membentuk kontrol perilaku yang tinggi sehingga membentuk niat untuk patuh konsumsi TTD teratur sepanjang tahun dengan benar. Remaja putri yang sedikit merasakan faktor pendukung dan banyak faktor penghambat untuk dapat melakukan perilaku konsumsi TTD teratur dengan patuh, maka remaja putri akan cenderung mempersepsikan diri sulit untuk melakukan perilaku tersebut. Remaja putri yang merasakan banyak faktor pendukung dan sedikit faktor penghambat untuk dapat melakukan perilaku patuh konsumsi TTD teratur, maka lebih besar kontrol yang mereka rasakan atas perilaku tersebut sehingga menghasilkan niat untuk patuh konsumsi TTD teratur.

Hasil tabulasi silang pada responden yang memiliki kontrol perilaku kuat (173 remaja putri) didapatkan 14,6\% memiliki niat tidak patuh. Artinya, meskipun remaja putri memiliki persepsi yang kuat akan kemudahan dalam berperilaku patuh mengonsumsi TTD teratur namun tetap memutuskan untuk berniat tidak patuh. Penjelasan dari hal tersebut dapat dilihat dari analisis 
jawaban angket responden yang memiliki kontrol perilaku kuat namun berniat tidak patuh. Hasil angket menunjukkan mayoritas responden memberikan skor 0 pada aspek efek samping yang akan dirasakan (pernyataan postif dan negatif). Hasil ini menunjukkan bahwa efek samping yang dirasakan adalah faktor penghambat terbesar sehingga responden memutuskan untuk berniat tidak patuh konsumsi TTD. Keyakinan tersebut dapat didasari oleh pengalaman individu yang berkaitan dengan perilaku konsumsi TTD, maupun oleh informasi lain mengenai perilaku yang diperoleh dari pengalaman orang-orang yang dikenalnya, teman-temannya dan oleh faktor lain yang meningkatkan persepsi kesulitan untuk melakukan suatu perilaku konsumsi TTD teratur (Ajzen, 2005).

\section{SIMPULAN}

Mayoritas responden memiliki persepsi kontrol perilaku kuat dan memiliki niat untuk patuh konsumsi TTD teratur. Ada hubungan antara kontrol perilaku dengan niat patuh dalam mengonsumsi TTD secara teratur. Remaja yang memiliki kontrol perilaku yang kuat akan memiliki niat untuk patuh konsumsi TTD teratur 3,906 kali dibandingkan remaja putri dengan kontrol perilaku lemah terhadap konsumsi TTD. Peningkatan pengetahuan dan persepsi kepada remaja putri tentang efek samping TTD perlu dilakukan melalui pendidikan kesehatan disekolah UKS secara kontinyu tentang pentingnya minum TTD dan manfaat yang dirasakan ketika minum TTD secara rutin. Penguatan niat untuk mengkonsumsi TTD secara rutin dan penguatan persepsi kontrol perilaku dari pihak sekolah dalam bentuk pengumuman waktu minum TTD melalui Whats app group maupun alarm di sekolah sebagai tanda minum TTD yang dapat dipantau oleh guru.

\section{DAFTAR PUSTAKA}

Aditianti, Permanasari, Y. and Julianti, E. D. (2015) 'Pendampingan Minum Tablet Tambah Darah (TTD) dapat Meningkatkan Kepatuhan Konsumsi TTD pada Ibu Hamil Anemia', Penelitian Gizi dan Makanan, 38(1), pp. 71-78.
Adriani, M. and Wirjatmadi, B. (2012) 'Peranan Gizi dalam Siklus Kehidupan', Jakarta: Kencana Prenada Media Group, 2, pp. 245278.

Ajzen, I. (2005) Atttudes, Personality and Behavior Second Edition. Second. Berkshire: Open University Press.

Aprianti, R., Sari, G. M. and Kusumaningrum, T. (2018) 'Factors Correlated with the Intention of Iron Tablet Consumption among Female Adolescents', 13(1).

Cahyaningrum, T. D. (2014) 'Faktorfaktor yang berhubungan dengan intensi (niat) remaja puteri dalam mengkonsumsi tablet $\mathrm{Fe}$ di SMP Negeri 1 Karangawen Kabupaten Demak (Skripsi)', Semarang: Program Studi S1 Keperawatan dan Kesehatan Universitas Muhammadiyah Semarang.

Dewi, R. C., Oktiawati, A. and Saputri, L. D. (2015) 'Teori \& Konsep Tumbuh Kembang Bayi, Toddler, Anak dan Usia Remaja', Yogyakarta: Nuha Medika.

Ekawati, Y. and Buton, L. D. (2018) 'Faktor Risiko Kejadian Kanker Payudara di RSU Bahteramas', Jurnal MJPH, 1(2), pp. 1-17.

Fishbein, M. and Ajzen, I. (2011) Predicting and changing behavior: The reasoned action approach. Taylor \& Francis.

Irianti, B. (2019) 'Hubungan Volume Darah pada saat Menstruasi dengan Kejadian Anemia pada Mahasiswa Akademi Kebidanan Internasional Pekanbaru Tahun 2014', Ensiklopedia of Journal, 1(2), pp. 257-261.

Irianto, K. (2014) 'Gizi Seimbang dalam Kesehatan Reproduksi'. Alfabeta.

Kementerian Kesehatan RI (2013) 'Riset Kesehatan Dasar 2013', Badan Penelitian dan Pengembangan Kesehatan Departemen Kesehatan Republik Indonesia, (Penyakit Menular), p. 103. doi: 10.1007/s13398-014-0173-7.2.

Kementerian Kesehatan RI (2016) Pedoman Pencegahan dan Penanggulangan Anemia pada Remaja Putri dan Wanita Usia Subur (WUS). Jakarta: Direktorat Kesehata Masyarakat.

Lestarina, N. N. W. (2018) 'Theory of Planned Behavior sebagai Upaya 
Peningkatan Kepatuhan pada Klien Diabetes Melitus', Media Kesehatan Masyarakat Indonesia, 14(2), p. 201. doi: $10.30597 / \mathrm{mkmi} . v 14 \mathrm{i} 2.3987$.

Nurcahyani, F. D. (2014) Hubungan Antara Body Image Dan Konsumsi Makanan Dengan Status Gizi Remaja Putri. Universitas Jember.

Putra, I. K. T. E., Sukaatmadja, I. P. . and Yasa, N. N. . (2016) 'Perilaku Konsumen Mengonsumsi Beras Organik di Kota Denpasar berdasar Theory of Planned Behavior', EJurnal Ekonomi dan Bisnis Universitas Udayana, 5(8), pp. 26092638.

Qamariyah, B. and Nindya, T. S. (2018) 'Hubungan Antara Asupan Energi, Zat Gizi Makro dan Total Energy Expenditure dengan Status Gizi Anak Sekolah Dasar Correlation between Energy Intake, Macro Nutrients and Total Energy Expenditure and Nutritional Status of Elementary Students', Amerta Nutrition, 2(1), pp. 59-65. doi: 10.20473/amnt.v2.i1.2018.59-65.

Ramdhani, N. (2016) 'Penyusunan Alat Pengukur Berbasis Theory of Planned Behavior', Buletin Psikologi, 19(2), pp. 55-69. doi: 10.22146/bpsi.11557.

Rismalinda (2017) Buku Ajar Psikologi. Jakarta: TIM.

Rosdiana, S. (2011) Faktor-faktor psikologis yang mempengaruhi intensi merokok pada remaja. Universitas Islam Negeri Syarif Hidayatullah.

Rosmalina, Y. and Ernawati, F. (2010) '( the Correlation of Micronutrient and Nutritional Status', hubungan status gizi mikro dengan status gizi anak rremaja SLTP, 33(1), pp. 14-22.

Sagitania (2017) 'Intensi Merokok Siswa SMP', Jurnal Psikologi Insight, 1(1), pp. 96-108. doi: 10.5281 /zenodo. 579558 .

Sastroasmoro, S. and Ismael, S. (2011) Dasar-Dasar Metodologi Penelitian Klinis. Jakarta: Sagung Seto.

Sya'Bani, I. R. N. and Sumarmi, S. (2016) 'Hubungan Status Gizi dengan Kejadian Anemia pada Santriwati di Pondok Pesantren Darul Ulum Peterongan Jombang', Jurnal Keperawatan Muhammadiyah, 1(1), pp. 7-15.

WHO (2011) 'Haemoglobin concentrations for the diagnosis of anaemia and assessment of severity', Geneva, Switzerland: World Health Organization, pp. 1-6. doi: 2011.

Wikamorys, D. . and Rochmach, T. . (2017) 'Aplikasi Theory of Planned Behavior Dalam Membangkitkan Niat Pasien Untuk Melakukan Operasi Katarak', Jurnal Administrasi Kesehatan Indonesia, 5(1), pp. 32-40. doi: 10.1037/0022-3514.51.6.1173.

Yuniarti; Rusmilawaty; Tunggal, T. (2015) 'Hubungan antara kepatuhan minum tablet $\mathrm{Fe}$ dengan kejadian anemia pada remaja putri di MA Darul Imad Kecamatan Tatah Makmur Kabupaten Banjar', Jurnal Publikasi Kesehatan Masyarakat Indonesia, 2(1), pp. 31-36. 